\title{
Impacts of wastewater discharge from Kalar city on Diyala-Sirwan river water quality, Iraq: pollution evaluation, health risks of heavy metals contamination
}

\author{
Hayder Mohammed Issa ${ }^{1}$ (1) - Azad H. Alshatteri ${ }^{2}$
}

Received: 29 June 2020 / Accepted: 23 March 2021 / Published online: 9 April 2021

(c) The Author(s) 2021

\begin{abstract}
In this work, a comprehensive assessment has been performed to understand impact of wastewater discharge from Kalar city on water quality parameters of Diyala-Sirwan river, Iraq. Levels of physicochemical parameters of $\mathrm{Ca}, \mathrm{K}, \mathrm{Na}, \mathrm{Mg}, \mathrm{pH}$, electrical conductivity, dissolved oxygen, total dissolved solid, turbidity, biological oxygen demand, and total hardness, and heavy metals of $\mathrm{Fe}, \mathrm{Mn}, \mathrm{Ni}, \mathrm{Cu}, \mathrm{Zn}, \mathrm{Hg}, \mathrm{Al}, \mathrm{Ba}$, Se, and As have been determined by inductively coupled plasma optical emission spectroscopy and other devices. Pollution indices, health risk assessment, and multivariate analysis have been applied to evaluate pollution intensity originated from wastewater discharge on river water quality at different locations, before and after the impact point. Pollution levels of slight to moderate have been identified using different indices for the river water at all sampling locations after the wastewater discharge point. Cluster and correlation analyses showed that the impact of wastewater discharge on the river water quality was occurring along the river within the study area. Non-carcinogenic health risk assessment for heavy metals in the river, indicating a potential risk, might on people's health, especially after discharge point. Furthermore, a significant effect of carcinogenic risk by heavy metals of As and $\mathrm{Hg}$ was recognized in the same area. This study thus helps to understand clearly the alteration that happened in the water quality of Diyala-Sirwan river due to the discharge of untreated wastewater from Kalar city.
\end{abstract}

Keywords Surface water pollution $\cdot$ Wastewater $\cdot$ Heavy metals $\cdot$ Pollution indices $\cdot$ Health risk assessment $\cdot$ Multivariate statistics

\section{Introduction}

Surface water quality is a key factor in water supply evaluation for authorities in urban and rural areas (Ismaiel et al. 2018). Usually, surface water quality is evaluated depending upon various physical, chemical, and biological parameters (Issa 2017). Since a great number of industrial effluents and sewage are likely to have been discharged into surface water sources, heavy metals are taken into consideration for effective quality evaluation of any surface water body (Kaushik

Hayder Mohammed Issa

hayder.mohammed@garmian.edu.krd

1 Department of Chemistry, College of Science, University of Garmian, Kurdistan Region,

Sulaimaniyah Province, 46021 Kalar city, Iraq

2 Chemistry Department, College of Education, University of Garmian, Kurdistan Region, Sulaimaniyah Province, 46021 Kalar city, Iraq et al. 2009; Mu et al. 2015; Ullah et al. 2019). Levels of heavy metals and other chemical quality parameters in surface waters are continuously changing due to various inputs, involving natural and anthropogenic sources (Ali et al. 2016; Muhammad and Ahmad 2020). Surface runoff and drainage water from rains have main contributions in carrying plenty of natural loads such as muds, soil, and humus into rivers (Begum et al. 2009). Industrial and urban discharges are the principal anthropogenic inputs of heavy metals and other chemicals in surface water bodies (Salah et al. 2012). River contamination with heavy metals is increasingly becoming an important issue, because of toxic, non-biodegradable behavior of heavy metals in aquatic biological systems (Jadoon et al. 2019; Varol and Şen 2012). Subsequently, heavy metals are likely to be transferred to humans, animals, and plants through consuming and using this contaminated water, posing serious health and life complications (Protano et al. 2014). Surface water quality assessment is commonly conducted to identify natural and anthropogenic sources 
causing pollution of surface water within a particular study area. Quality assessment for cases when a pollution source has been identified gives further illustrations about how pollutants were readily dispersed and distributed in the water body.

Many former studies have been performed on river pollution caused by city wastewater discharges. Several of these works found that river pollution in cities is mainly attributed to heavy metal pollution (Abdel-Satar et al. 2017). For river water quality assessment, studies showed that mostly various heavy metals in water samples have high concentrations than the normal levels (Bhuiyan et al. 2014; Diagomanolin et al. 2004; Reza and Singh 2010). Physicochemical parameters are also being used for water quality assessment. Combining heavy metals with other water quality parameters helps to have a general view on surface water quality condition, as physicochemical parameters water may reveal significant pollution situations as well (Özgür et al. 2012). Various ways have been adopted to evaluate heavy metals and other parameters for surface water quality: the degree of contamination index $\left(\mathrm{C}_{\mathrm{d}}\right)$ to determine combined effects of risky quality parameters in water (Bhuiyan et al. 2010); water quality index (WQI); heavy metals evaluation index (HEI) (Singaraja et al. 2015); pollution index (PLI); heavy metals pollution index (HPI) to identify heavy metal pollution in water (Cengiz et al. 2017; Prasad and Bose 2001; Reza and Singh 2010); and multivariate statistics (Giri and Singh 2014; Nasrabadi 2015; Simeonov et al. 2003; Wu et al. 2018).

Nearly all rivers in Iraq are suffering from low-quality level and pollution (Hassan et al. 2010; Ibrahim 2012; Kamil and Adel Abdulrazzaq 2010), as a result of industrial and rural wastewater discharges. Several attempts have been established to define potential risks on surface water resources from these discharges for different parts of Iraq (Aziz et al. 2018; Aziz and Fakhrey 2016; Issa 2014; Razzak and Sulaymon 2009; Wissam and Isam 2017). Till now, few studies have been conducted to determine heavy metals and other physicochemical concentration levels in Diyala-Sirwan river (Abdullah 2013; Hassan et al. 2017; Issa and Alshatteri 2018). However, the previous studies were generally investigating the water quality of DiyalaSirwan river without focusing on an identified source of pollution for the river. This work demonstrates the impact of wastewater discharge from Kalar city on increasing heavy metal concentrations and physicochemical parameters in Diyala-Sirwan river, and their consequences on health and life of the people of the region. The evaluation was made by using various heavy metals pollution and risk assessment indices with different statistical and multivariate methods such as analysis of variance (ANOVA), Friedman test, Pearson correlation analysis matrix (CM), and cluster analysis (CA) and box plots to identify pollution levels. This work aids to establish a trustworthy evaluation of wastewater discharges impact on Diyala-Sirwan river quality, by which further development can be achieved in remediation policies that applied to improve the environmental and health programs in the region.

\section{Materials and methods}

\section{Description of the study area}

The study area Kalar city $\left(34^{\circ} 37^{\prime} \mathrm{N}, 45^{\circ} 19^{\prime} \mathrm{E}\right)$ is located in the south of Sulaimaniyah Province, east of Iraq (Fig. 1), and is about $200 \mathrm{~km}$ northeast of Baghdad. Kalar city has become increasingly populated in the last two decades. The population expansion happened due to both natural economic development and to the unusual ongoing political situation in Iraq. Kalar city of about $281 \mathrm{~K}$ population (Kurdistan Region Statistics Office 2020), and comprising many commercial and industrials activities with agricultural in suburban areas as well, which lastly are discharged into Diyala-Sirwan river without treatment. The annual rainfall of the city is $273 \mathrm{~mm}$ with no precipitation in the summer season (Garmian Region Agriculture Department 2017).

\section{Water sample collection and preparation}

In the study area, water samples were collected from sampling locations from four locations along Diyala-Sirwan river in January 2019: L1 before impact point of Kalar city wastewater discharge, by $10 \mathrm{~km}$; L2 directly at the impact point of wastewater discharge; L3 after $5 \mathrm{~km}$ from impact point; and L4 at $10 \mathrm{~km}$ from the impact point. The selected water sampling locations cover a stretch of about $20 \mathrm{~km}$ (Fig. 1). At each site, three water samples were collected in clean polyethylene containers of a $250 \mathrm{ml}$ volume, in which water samples were allowed to remain in containers only for a while before taking to analysis. All water samples have been prepared for analysis of heavy metals were acidified with $2 \%$ nitric acid $\left(\mathrm{pH}^{<} 2\right)$, and refrigerated and transferred to the instrumental research laboratory, within 1 to $2 \mathrm{~h}$ from the time of collection and stored in a dark place. For dilutions and glassware washing, distilled deionized water always has been used (Marcovecchio et al. 2007). Standard solutions used by ICP-OES analysis were prepared by diluting with several dilutions of concentrations of $0.1,0.5,2$ ppm into $0.5 \%$ nitric acid, which was used as a diluent (Aris et al. 2013). 


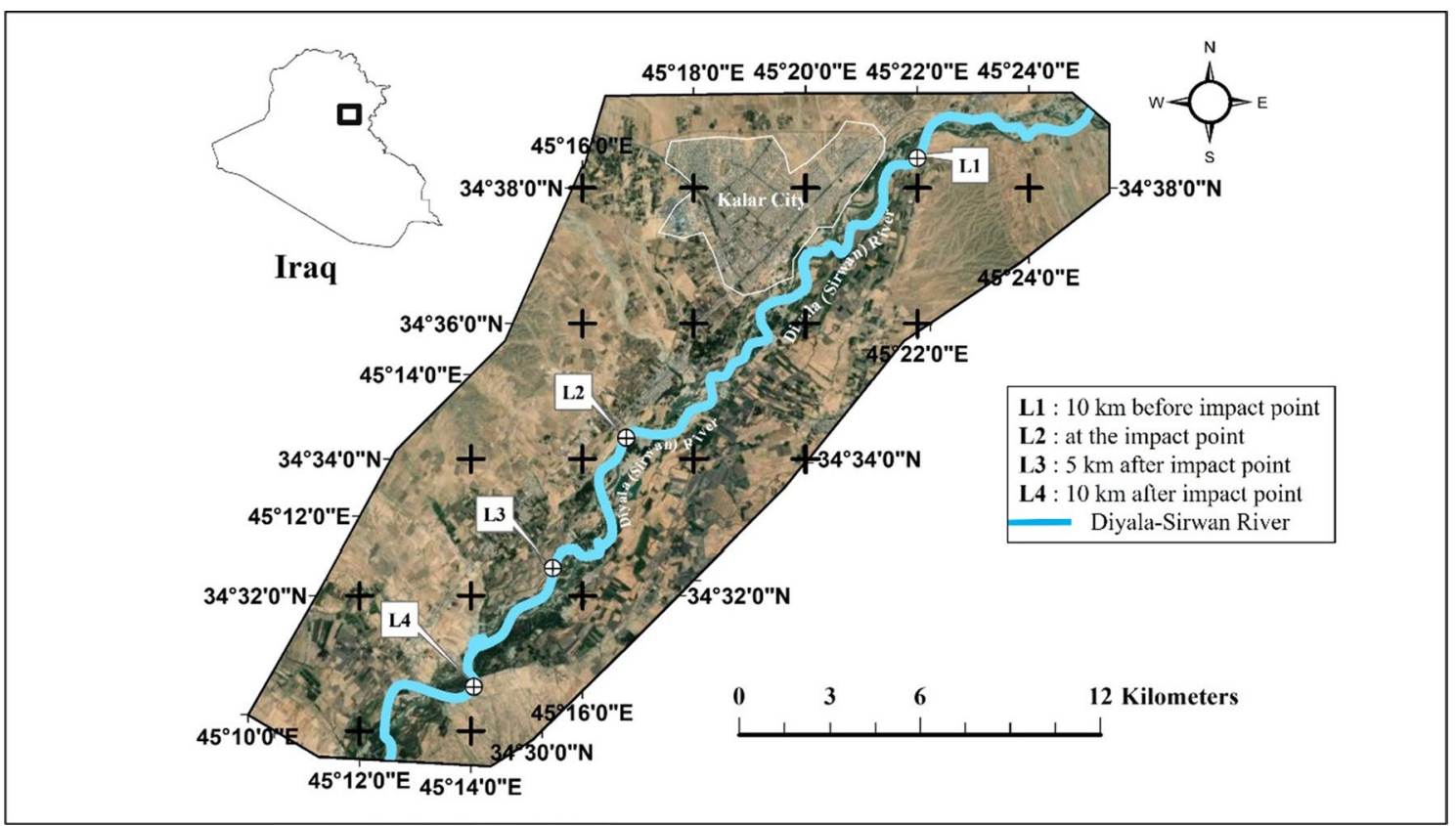

Fig. 1 The study area with showing sampling locations

\section{Water samples analysis}

In the laboratory, all returned water samples for heavy metals analysis and other chemical elements were acidified by adding concentrated nitric acid $\mathrm{HNO}_{3}$ and stored at $25^{\circ} \mathrm{C}$. The analysis was done at the University of Garmian laboratories by using inductively coupled plasma optical emission spectroscopy, ICP-OES, (Spectro across Germany). The standard solutions were prepared by serial dilutions of the $1000 \mathrm{mg} / \mathrm{L}$ used to analysis ten heavy metals of $\mathrm{Fe}, \mathrm{Mn}, \mathrm{Ni}$, $\mathrm{Cu}, \mathrm{Zn}, \mathrm{Hg}, \mathrm{Al}, \mathrm{Ba}, \mathrm{Se}$, and $\mathrm{As}$ and four chemical elements of $\mathrm{Ca}, \mathrm{K}, \mathrm{Na}$, and $\mathrm{Mg}$. Instrument conditions of ICP-OES were: RF power/W equals 1400; pump speed was about $30 \mathrm{rpm}$; coolant flow equals $14 \mathrm{~L} / \mathrm{min}$; measure time was $28 \mathrm{~s}$; replicate measurements were 3 .

Water samples were also analyzed over the same period for physicochemical water quality parameters of $\mathrm{pH}$, electrical conductivity (EC), dissolved oxygen (DO), total dissolved solid (TDS), turbidity, biological oxygen demand (BOD), and total hardness (TH) at the University of Garmian laboratories by following analysis procedures according to APHA (Rice et al. 2017). These parameters are chosen to evaluate Kalar city wastewater discharge, as they are highly relevant to the occurring Diyala-Sirwan river quality variation concerning the suitability for drinking and various purposes by people of the study area. The accuracy of the analysis method was verified, randomly selected samples their analysis was duplicated.

\section{Water samples pollution assessment}

\section{Heavy metal pollution index (HPI)}

HPI as proposed by Mohan et al. (Mohan et al. 1996), by which water quality was assessed in terms of heavy metals importance in water samples. HPI calculation is based on an arithmetic mean a method that converts water existing data into a sole number in terms of heavy metals presence impact on water quality as following equations,

$Q_{i}=\sum_{i=1}^{n} \frac{\left[M_{i \text { Salahetal }, 2012}(-) I_{i}\right]}{\left(S_{i}-I_{i}\right)} * 100$

$H P I=\frac{\sum_{i=1}^{n} W_{i} Q_{i}}{\sum_{i=1}^{n} W_{i}}$

$\mathrm{M}_{\mathrm{i}}, \mathrm{S}_{\mathrm{i}}$, and $\mathrm{I}_{\mathrm{i}}$ are monitored, standard, and ideal values of i-parameter for the investigated heavy metals, $Q_{i}$ is the sub-index of i-parameter, $\mathrm{W}_{\mathrm{i}}$ is the weight of $\mathrm{i}$-parameter, and $\mathrm{n}$ is the total number of parameters in a test. For each parameter, $\mathrm{W}_{\mathrm{i}}$ is inversely proportional to the recommended standard. 


\section{Heavy metals evaluation index (HEI)}

HEI is applied to identify water contamination by heavy metals, and heavy metal evaluation index is calculated as following (Boateng et al. 2015),

$H E I=\sum_{i=1}^{n} \frac{H_{c}}{H_{m a c}}$

where $\mathrm{H}_{\mathrm{c}}$ and $\mathrm{H}_{\mathrm{mac}}$ are the observed and maximum permissible level concentrations for each i-parameter, respectively.

\section{Contamination index $\left(C_{d}\right)$}

For $\mathrm{C}_{\mathrm{d}}$, a sum of individual contamination parameters above the upper allowable limits as the following (Edet and Offiong 2002),

$C_{d}=\sum_{i=1}^{n} C_{f i}$

$C_{f i}=\frac{C_{A i}}{C_{N i}}-1$

$\mathrm{C}_{\mathrm{f}}, \mathrm{C}_{\mathrm{Ai}}$, and $\mathrm{C}_{\mathrm{Ni}}$ are concentration factor, analytical value, and the upper allowable concentration of the i-parameter, respectively.

\section{Water Pollution index (PI) and overall index of pollution (OIP)}

Pollution index (PI) evaluates water pollution by metals that originated from different origins. PI is a normalized factor, is a concentration ratio of quality parameters, and their background values as the following equation (Goher et al. 2014).

$\mathrm{PI}=\frac{\sqrt{\left[\left(\frac{C_{i}}{S_{i}}\right)_{\text {max }}^{2}+\left(\frac{C_{i}}{S_{i}}\right)_{\text {min }}^{2}\right]}}{2}$

$\mathrm{C}_{\mathrm{i}}$ is parameter concentration, and $\mathrm{S}_{\mathrm{i}}$ is standard (background) concentration $(\mathrm{mg} / \mathrm{kg})$ of the same parameter in water sample. For PI, five classifications were considered: no effect pollution $(\mathrm{PI}<1.0)$; slightly affected $(1.0 \leq \mathrm{PI}<2.0)$; moderately affected $(2.0 \leq \mathrm{PI}<3.0)$; strongly affected $(3.0 \leq \mathrm{PI} \leq 5.0)$; and extremely affected $(\mathrm{PI}>5.0)$.

To estimate various pollution sources affecting surface water quality, an average of all individual water quality parameters was proposed by (Sargaonkar and Deshpande 2003) as the following equation
$\mathrm{OIP}=\frac{\sum_{i} P_{i}}{n}$

where $\mathrm{Pi}$ is the ith parameter pollution index, and $\mathrm{n}$ is the number of parameters included in pollution evaluation. According to measured values of water quality parameters, integer values have been assigned to these parameters (from 1 to 16 ) to classify surface water quality by indicating the pollution level for each parameter (Issa 2014). OIP classifies surface water quality into five main classes: 0-1 excellent; 1-2 acceptable; 2-4 slightly polluted; 4-8 polluted; and 8-16 heavily polluted (Sharda and Sharma 2013).

\section{Health risk assessment of river samples}

Risk assessment of water samples for heavy metals was made using previous methods for two types of exposure: ingestion and dermal absorption ( $\mathrm{Li}$ and Zhang 2010). The dose received by human pathways is determined by the following two equations that simulate a chemical daily intake $(\mu \mathrm{g} / \mathrm{kg} /$ day $)$ by ingestion $\left(\mathrm{CDI}_{\text {ingestion }}\right)$ and dermal exposure $\left(\mathrm{CDI}_{\text {dermal }}\right)$ according to US Environmental Protection Agency (US EPA 2004; Wu et al. 2009):

$C D I_{\text {ingestion }}=\frac{\left(C_{W} * I R * A B S_{g} * E F * E D\right)}{B W * A T}$

$C D I_{\text {dermal }}=\frac{\left(C_{W} * S A * K_{p} * A B S_{d} * E T * E F * E D * C F\right)}{B W * A T}$

where $\mathrm{C}_{\mathrm{W}}$ is the average concentration of heavy metals in water $(\mu \mathrm{g} / \mathrm{L})$, IR is ingestion rate (in this work it was considered to be 2.5 (L/day), $\mathrm{ABS}_{\mathrm{g}}$ is gastrointestinal adsorption factor, $\mathrm{ABS}_{\mathrm{d}}$ is dermal adsorption factor, $\mathrm{EF}$ is exposure frequency (in this work 365 days/year was adopted), ED is exposure duration (in this work 65 years was assumed), BW is the average body weight (in this work $75 \mathrm{~kg}$ was assumed), AT is averaging time (for non-carcinogens and carcinogens is 25550 days), SA is exposed area of skin (in this work 2800 $\mathrm{cm}^{2}$ was adopted from (De Miguel et al. 2007)), $\mathrm{K}_{\mathrm{p}}$ is skin adherence factor $(\mathrm{cm} / \mathrm{h}), \mathrm{ET}$ is the exposure time (in this work $0.5 \mathrm{~h}$ /day was assumed), $\mathrm{CF}$ is a unit conversion factor, for water equals $1 \mathrm{~L} / 1000 \mathrm{~cm}^{3}$.

For non-carcinogen risk, the risk on human life and health was assessed by applying hazard quotients (HQ) for heavy metals and hazard index (HI) (Tripathee et al. 2016; Wang et al. 2017).

$H Q=\frac{C D I}{R f D}$ 
$H I=\sum H Q s$

CarcinogenicRisk $=1-\exp (-C D I * S F)$

where RfD is the reference dose for a toxic element $(\mu \mathrm{g} / \mathrm{kg}$ d), the $\mathrm{RfD}_{\text {ingestion }}$ and $\mathrm{RfD}_{\text {dermal }}$ for non-carcinogen toxic heavy metals investigated in this work were adapted from (De Miguel et al. 2007; Li and Zhang 2010; US EPA 2004; Wu et al. 2009), while $K_{p}$ values were adapted from (US EPA 2004; Wang et al. 2017). SF value for carcinogenic heavy metal for As was taken from (Giri and Singh 2015).

\section{Statistical analysis}

River water samples analysis from the different sampling locations was subjected to several statistical analyses: ANOVA; CM; Friedman test; and CA. These statistical analysis helps to determine spatial differences of physicochemical and heavy metals qualities for Diyala-Sirwan river for pre- and post-discharging of wastewater of Kalar city into the river. ANOVA and Friedman tests were used to recognize the differences in the mean values of tested parameters in river water samples before and after the impact point at different distances. CM identifies the strength of relationships between the investigated heavy metals and water physicochemical parameters. CA was performed to categorize river water samples due to variation of physicochemical and heavy metal parameters based on Ward-algorithmic linkage and Euclidean distance methods. Cluster analysis was conducted using XLSTAT, version 2014 for Excel 2013 software.

\section{Results and discussion}

\section{River water quality and wastewater discharge impacts}

The concentrations of water quality parameters taken at different locations from Diyala-Sirwan river in January 2019 within the study area are shown in Table 1. At each site, 21 heavy metals and physicochemical properties were measured or analyzed for river water samples. Four sampling locations (L1, L2, L3, and L4) have been chosen to demonstrate the impact of wastewater discharge from Kalar city on the water quality of the river.

However, from Table 1, it can be seen that EC, TDS, $\mathrm{TH}$, temperature, $\mathrm{K}, \mathrm{Na}$, and $\mathrm{Mg}$ at the four investigated locations are lower than the maximum admissible limit (MAL). Also, concentrations of heavy metals of As, Ba, $\mathrm{Cu}, \mathrm{Fe}, \mathrm{Ni}, \mathrm{Se}$, and $\mathrm{Zn}$ at the four locations are lower than MAL. At impact point sampling location, L2, it can be seen there is a spike in concentrations for all investigated river water quality parameters of physicochemical and heavy metals. Water samples collected from the location L2 reveal a significant deterioration in water quality, all physicochemical parameters, and heavy metals were at elevated levels, close to or higher than MAL, showing the harmful effect of wastewater discharging without treatment into the river water body.

DO was effectively lowered from 9.56 to $4.5 \mathrm{mg} / \mathrm{L}$ at locations L1 and L2, respectively. Turbidity was highly elevated due to wastewater discharge as it can be observed that it was $6.88 \mathrm{NTU}$ at L1 and then was increased to 78.2 NTU at L2. At location $\mathrm{L} 2, \mathrm{pH}, \mathrm{Hg}$, and $\mathrm{Mn}$ increased from acceptable levels to be higher than MAL, but $\mathrm{pH}$ was returned to be normal at the locations $\mathrm{L} 3$ and $\mathrm{L} 4$, while $\mathrm{Hg}$ and $\mathrm{Mn}$ concentrations remained to be higher than MAL at the locations L3 and L4. Additionally, Table 1 shows that $\mathrm{Ca}$ and $\mathrm{Al}$ concentrations were already elevated in the river before expelling the wastewater of Kalar city, indicating that natural weathering of soils and rocks of river banks might be the source of high concentrations of $\mathrm{Ca}$ and $\mathrm{Al}$ in the river beside the wastewater of Kalar city. In general, it has been noticed that the water of Diyala-Sirwan river is significantly influenced by Kalar city wastewater discharge especially at the impact point and subsequently at locations after various distances. Discharging untreated wastewater to the river imposes a considerable decline in water properties, suggesting a disturbing in the aquatic life and water quality for drinking, agricultural and urban uses with the study area. Therefore, to some extent, the direct use of Diyala-Sirwan river without treatment at the study area for domestic and agricultural purposes is undesirable. As seen in Table 1, wastewater impact concerned appears to be within an acceptable range, when comparing with some physicochemical rates influenced by wastewater discharges for similar rivers cases in Iraq.

A noticeable increase in heavy metals concentration at/ after impact point of wastewater discharge shows that many heavy metals were originated by anthropogenic activities in Kalar city and then transported in wastewater such as $\mathrm{As}, \mathrm{Cu}, \mathrm{Fe}, \mathrm{Hg}, \mathrm{Mn}$, and $\mathrm{Zn}$. Sources of such metals are likely to be tap water and roofs, galvanized material and car washes, the amalgam in teeth for $\mathrm{Cu}, \mathrm{Zn}$, and $\mathrm{Hg}$, respectively (Sörme and Lagerkvist 2002).

\section{Statistical analysis}

\section{Analysis of variance}

ANOVA at 95\% confidence level for the sampling locations showed no significant difference in Diyala-Sirwan river water quality caused by Kalar city wastewater discharge and

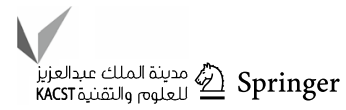


Table 1 Average data of physicochemical and heavy metals parameters for DiyalaSirwan river and impact points of the Kalar city wastewater discharge compared with results of other Iraqi rivers

\begin{tabular}{|c|c|c|c|c|c|c|c|c|c|c|c|}
\hline \multirow[t]{2}{*}{ Parameter } & \multicolumn{4}{|c|}{ Sampling locations } & \multicolumn{2}{|c|}{ Tigris $^{f}$} & \multicolumn{2}{|c|}{ Euphrates ${ }^{g}$} & \multicolumn{2}{|c|}{ Greater $\mathrm{Zab}^{\mathrm{h}}$} & \multirow[t]{2}{*}{$\mathrm{MAL}^{\mathrm{a}}$} \\
\hline & L1 & L2 & L3 & L4 & B.M & A.M & B.M & A.M & B.M & A.M & \\
\hline $\mathrm{EC}(\mu \mathrm{S} / \mathrm{cm})$ & 507.00 & 941.00 & 516.00 & 520.00 & & & 1194 & 1186 & 361.3 & 748.3 & $1400.0^{\mathrm{c}}$ \\
\hline DO (mg/L) & 9.56 & 4.50 & 9.41 & 9.52 & & & & & 5.8 & 4.37 & $\geq 5.0^{\mathrm{b}}$ \\
\hline TDS (mg/L) & 450.00 & 810.00 & 470.00 & 480.00 & 432 & 576 & 998 & 936 & 300 & 433.3 & $1000.0^{\mathrm{d}}$ \\
\hline Turbidity (NTU) & 6.88 & 78.20 & 20.30 & 16.10 & 7.4 & 4.3 & 17 & 15 & 59.8 & 71.02 & $5.0^{\mathrm{e}}$ \\
\hline $\mathrm{pH}$ (pH degree) & 8.60 & 5.90 & 7.80 & 7.60 & 8.3 & 8.2 & 7.6 & 8.3 & 7.9 & 8.21 & $6.5-8.5^{b}$ \\
\hline Temp. $\left({ }^{\circ} \mathrm{C}\right)$ & 18.5 & 19.0 & 17.5 & 18.0 & & & & & 12.26 & 14.37 & $35.0^{b}$ \\
\hline BOD (mg/L) & 1.33 & 4.23 & 1.66 & 1.57 & 2.0 & 4.0 & 2 & 3 & 1.53 & 4.27 & $5.00^{\mathrm{b}}$ \\
\hline T. H. (mg/L) & 337.27 & 410.20 & 379.84 & 396.20 & 430 & 390 & 426.8 & 395.7 & 174 & 281.3 & 500.0 \\
\hline $\mathrm{Ca}(\mathrm{mg} / \mathrm{L})$ & 97.68 & 113.89 & 106.48 & 110.70 & & & 101.4 & 103 & & & 75.00 \\
\hline $\mathrm{K}(\mathrm{mg} / \mathrm{L})$ & 2.63 & 10.12 & 2.93 & 2.93 & & & 4.6 & 4.8 & & & 12.00 \\
\hline $\mathrm{Na}(\mathrm{mg} / \mathrm{L})$ & 14.48 & 49.12 & 17.61 & 18.54 & 52 & 48 & 142 & 136 & & & 50.00 \\
\hline $\mathrm{Mg}(\mathrm{mg} / \mathrm{L})$ & 22.70 & 30.61 & 27.72 & 29.14 & & & 53.9 & 35.3 & & & 50.00 \\
\hline $\mathrm{Al}(\mathrm{mg} / \mathrm{L})$ & 0.138 & 0.183 & 0.176 & 0.223 & & & & & & & 0.10 \\
\hline As (mg/L) & 0.006 & 0.007 & 0.01 & 0.007 & & & & & & & 0.05 \\
\hline $\mathrm{Ba}(\mathrm{mg} / \mathrm{L})$ & 0.08 & 0.075 & 0.071 & 0.072 & & & & & & & 0.70 \\
\hline $\mathrm{Cu}(\mathrm{mg} / \mathrm{L})$ & 0.013 & 0.006 & 0.014 & 0.032 & & & & & & & 1.00 \\
\hline $\mathrm{Fe}(\mathrm{mg} / \mathrm{L})$ & 0.02 & 0.134 & 0.034 & 0.05 & & & & & & & 0.20 \\
\hline $\mathrm{Hg}(\mathrm{mg} / \mathrm{L})$ & 0.006 & 0.028 & 0.019 & 0.016 & & & & & & & 0.01 \\
\hline $\mathrm{Mn}(\mathrm{mg} / \mathrm{L})$ & 0.005 & 0.066 & 0.007 & 0.008 & & & & & & & 0.05 \\
\hline $\mathrm{Ni}(\mathrm{mg} / \mathrm{L})$ & 0.004 & 0.005 & 0.005 & 0.004 & & & & & & & 0.07 \\
\hline $\mathrm{Se}(\mathrm{mg} / \mathrm{L})$ & 0.009 & 0.019 & 0.016 & 0.013 & & & & & & & 0.04 \\
\hline $\mathrm{Zn}(\mathrm{mg} / \mathrm{L})$ & 0.005 & 0.022 & 0.007 & 0.014 & & & & & & & 3.00 \\
\hline
\end{tabular}

MAL Maximum allowable limit; B.M. before mixing; $A . M$. after mixing.

a adopted from (Issa and Alshatteri 2018) unless otherwise indicated

${ }^{\mathrm{b}}$ Iraqi maximum admissible limit; ${ }^{\mathrm{c}}$ adopted from (Edet and Offiong 2002).

${ }^{\mathrm{d}}$ adopted from (Effendi 2016)

e adopted from (World Health Organization 2017)

fadopted from (Razzak and Sulaymon 2009)

gadopted from (Mahmood 2010)

hadopted from (Aziz and Fakhrey 2016) among waster sampling location, as F value, F critical, and p-value were $0.273,2.71$, and 0.845 , respectively.

Friedman test resulted in a ranked table for the investigated variables according is presented as Table 2. The calculated Chi-square was 188.91 which is highly greater than the value of 3.84146 found from the state decision rule list for alpha $=0.05, k=2$, showing that a significant difference is occurring between the two conditions of pre- and postimpact point.

\section{Friedman test analysis}

Friedman test analysis is a non-parametric statistical tool that is mostly used to identify the variations in group sets of obtained data. In this work, the difference between the two conditions of Diyala-Sirwan river, pre- and post-impact point of wastewater discharge, has been investigated for alpha equals 0.05 . Similar ANOVA hypotheses of null $\left(\mathrm{H}_{0}\right)$ and alternative hypotheses $\left(\mathrm{H}_{1}\right)$ were used to double-check the results of ANOVA.

\section{Correlation analysis matrix (CM)}

$\mathrm{CM}$ gives numbers, if they are closer to -1 or +1 , indicating strong correlation, whereas numbers closer to zero are meaning a weak correlation. In this work, Pearson correlation analysis was performed for river water samples of the post-impact point of wastewater discharge at a significant level of 0.05 , as illustrated in Table 3 .

$\mathrm{CM}$ of the 22 physicochemical and heavy metals parameters in river water samples after wastewater discharge shows various strong (higher than 0.7 ,) positive or negative correlations.

Table 3 exhibits many strong positive relationships, between EC, DO, TDS, turbidity, BOD, TH, temperature, 
Table 2 The generated ranked values of the investigated variables using Friedman test analysis

\begin{tabular}{|c|c|c|c|c|}
\hline Parameter & $\begin{array}{l}\text { Pre-impact pt. mean } \\
\text { values }\end{array}$ & $\begin{array}{l}\text { Post-impact pt. mean } \\
\text { values }\end{array}$ & $\begin{array}{l}\text { Pre-impact ranked } \\
\text { values }\end{array}$ & $\begin{array}{l}\text { Post-impact } \\
\text { ranked } \\
\text { values }\end{array}$ \\
\hline $\mathrm{EC}(\mu \mathrm{S} / \mathrm{cm})$ & 507.000 & 659.000 & 1 & 2 \\
\hline DO (mg/L) & 9.560 & 7.810 & 2 & 1 \\
\hline TDS (mg/L) & 450.000 & 586.667 & 1 & 2 \\
\hline Turbidity (NTU) & 6.880 & 38.200 & 1 & 2 \\
\hline $\mathrm{pH}(\mathrm{pH}$ degree $)$ & 8.600 & 7.100 & 2 & 1 \\
\hline $\mathrm{BOD}(\mathrm{mg} / \mathrm{L})$ & 1.330 & 2.487 & 1 & 2 \\
\hline T. H. (mg/L) & 337.270 & 395.413 & 1 & 2 \\
\hline Temp. $\left({ }^{\circ} \mathrm{C}\right)$ & 18.500 & 18.167 & 2 & 1 \\
\hline $\mathrm{Ca}(\mathrm{mg} / \mathrm{L})$ & 97.682 & 110.357 & 1 & 2 \\
\hline $\mathrm{K}(\mathrm{mg} / \mathrm{L})$ & 2.626 & 5.326 & 1 & 2 \\
\hline $\mathrm{Na}(\mathrm{mg} / \mathrm{L})$ & 14.478 & 28.423 & 1 & 2 \\
\hline $\mathrm{Mg}(\mathrm{mg} / \mathrm{L})$ & 22.700 & 29.153 & 1 & 2 \\
\hline $\mathrm{Al}(\mathrm{mg} / \mathrm{L})$ & 0.138 & 0.194 & 1 & 2 \\
\hline As (mg/L) & 0.006 & 0.008 & 1 & 2 \\
\hline $\mathrm{Ba}(\mathrm{mg} / \mathrm{L})$ & 0.080 & 0.073 & 2 & 1 \\
\hline $\mathrm{Cu}(\mathrm{mg} / \mathrm{L})$ & 0.013 & 0.017 & 1 & 2 \\
\hline $\mathrm{Fe}(\mathrm{mg} / \mathrm{L})$ & 0.020 & 0.073 & 1 & 2 \\
\hline $\mathrm{Hg}(\mathrm{mg} / \mathrm{L})$ & 0.006 & 0.021 & 1 & 2 \\
\hline $\mathrm{Mn}(\mathrm{mg} / \mathrm{L})$ & 0.005 & 0.027 & 1 & 2 \\
\hline $\mathrm{Ni}(\mathrm{mg} / \mathrm{L})$ & 0.004 & 0.005 & 1 & 2 \\
\hline $\mathrm{Se}(\mathrm{mg} / \mathrm{L})$ & 0.009 & 0.016 & 1 & 2 \\
\hline $\mathrm{Zn}(\mathrm{mg} / \mathrm{L})$ & 0.005 & 0.014 & 1 & 2 \\
\hline Sum of ranks & & & 26 & 40 \\
\hline
\end{tabular}

$\mathrm{Ca}, \mathrm{K}, \mathrm{Na}, \mathrm{Mg}, \mathrm{Ba}, \mathrm{Fe}, \mathrm{Hg}, \mathrm{Mn}$, Se, and Zn. Similarly, strong positive relationships between heavy metals were observed: among $\mathrm{Ba}, \mathrm{Al}, \mathrm{Fe}, \mathrm{Hg}, \mathrm{Mn}, \mathrm{Se}$, and $\mathrm{Zn}$. Strong negative relationships were found for $\mathrm{DO}$ and $\mathrm{pH}$ with turbidity, TDS, $\mathrm{BOD}, \mathrm{Ba}, \mathrm{Fe}, \mathrm{Hg}, \mathrm{Mn}, \mathrm{Se}$, and $\mathrm{Zn}$. Similarly, strong relationships were found between heavy metals: $\mathrm{Al}$ with $\mathrm{Ni}$ and $\mathrm{Se}$; As with $\mathrm{Zn} ; \mathrm{Cu}$ with $\mathrm{Hg}, \mathrm{Mn}, \mathrm{Ni}$, and $\mathrm{Se}$.

High positive relationships between physicochemical parameters and heavy metals suggest that similar inputs sources of chemical pollutants come in urban wastewater discharge into the river (Bastami et al. 2012). Also, strong relationships between heavy metals in the river after the impact point suggest similar input sources and transport ways of these metals (Jiang et al. 2014).

Negative strong correlations between $\mathrm{pH}$ and most of the investigated physicochemical and heavy metals parameters in river water refer to the fact that low $\mathrm{pH}$ in the river water leads to an increase in heavy metals and chemical parameters solubility (Gonzalez et al. 1990). Lowered concentrations of heavy metals in river water gradually from impact point location were due to the formation of insoluble higher oxides and hydroxides of the heavy metals resulting in their precipitation (Suresh et al. 2012).

\section{Cluster analysis (CA)}

CA analysis was conducted to identify similarities among clustered results that were established by this method by presenting internal clusters homogeneity and significant external heterogeneity between clusters. CA in this study was applied based on spatial similarity among river water samples of sampling locations in the study area.

From the results presented in Fig. 2, a dendrogram of cluster analysis result established three distinct clusters depending on the similarity of physicochemical parameters and heavy metals in river water samples for sampling locations. Cluster 1 which represents the location L2, the wastewater discharge impact point, is noticeably different from other clusters, at which a high pollutant input is occurring and leading to a significant deterioration in the water quality of the river.

Cluster 3 was for locations L3 and L4, water samples in this cluster were quite similar and, at the same time, were different from cluster 2 (L1 location), meaning that the river did not fairly overcome the high input of pollutants due to wastewater discharge even though at $10 \mathrm{~km}$ from the impact point. It can be assumed that due to the high loud of pollutants that discharged at point L2 the river

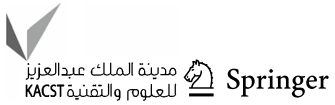




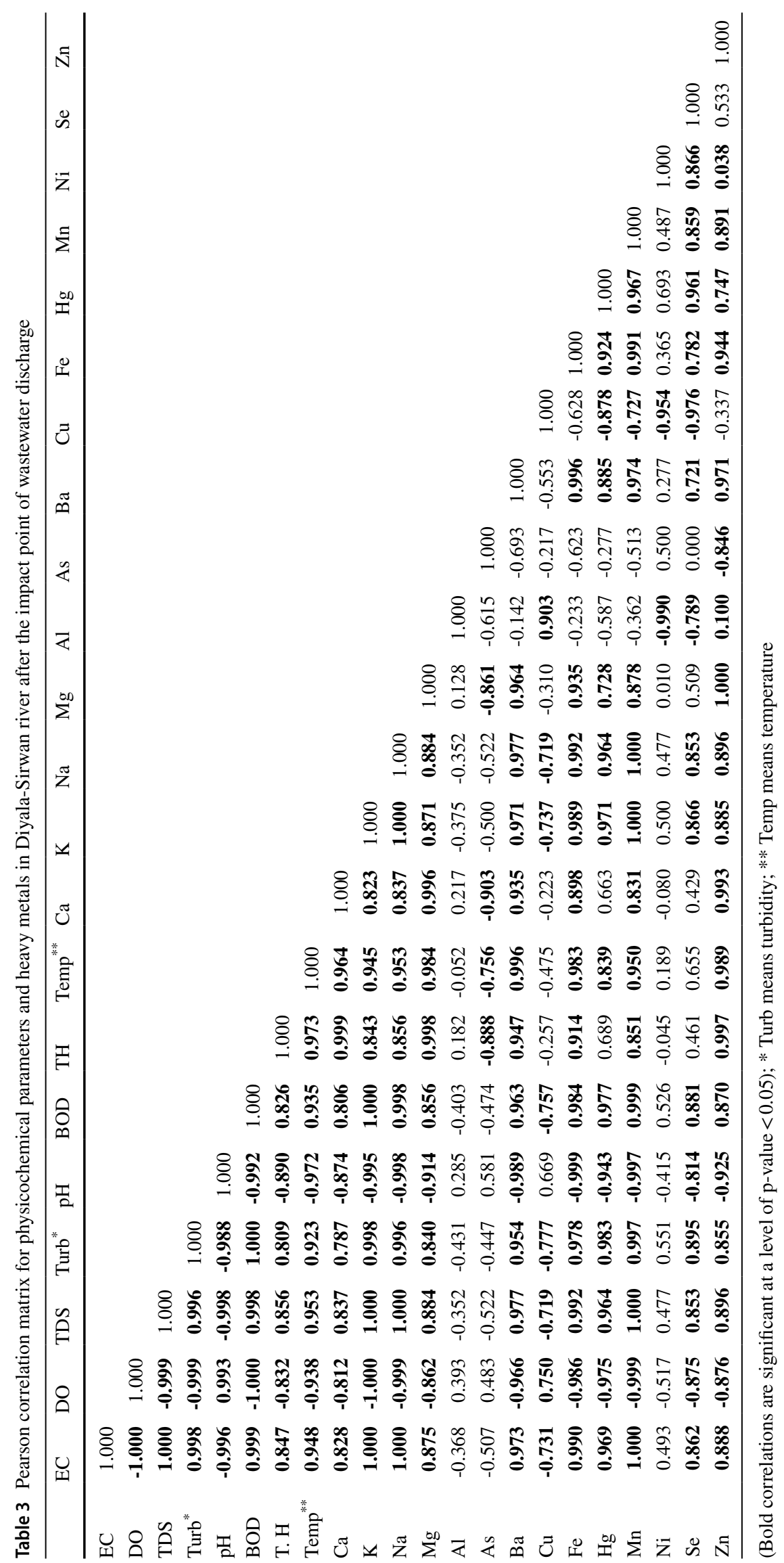




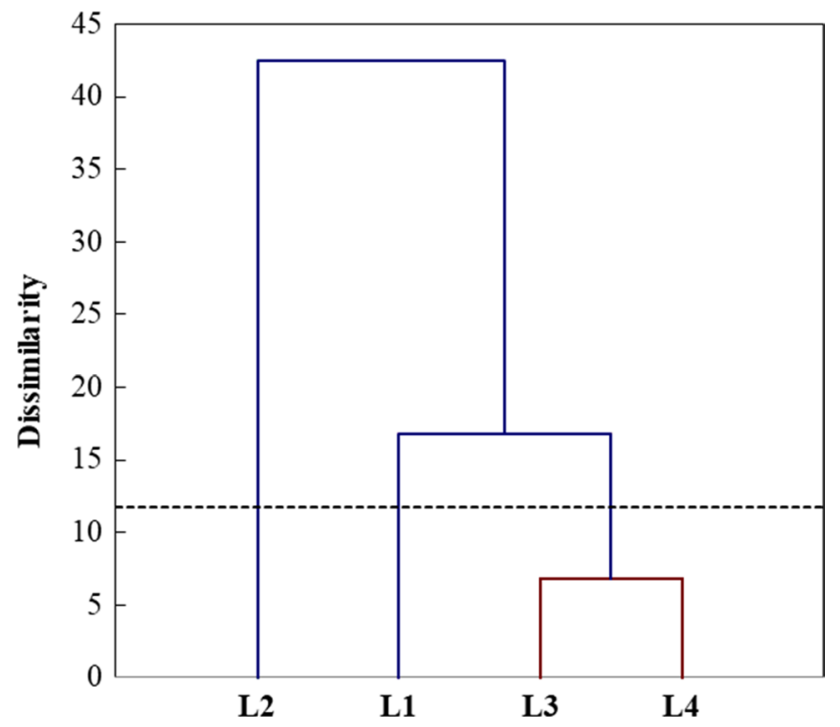

Fig. 2 Dendrogram of cluster analysis results for the four water sampling locations

self-purification process takes longer time and distance than $10 \mathrm{~km}$ to retain the same water quality of location L1, before impact point, therefore, as shown from CA, the influence of pollutants in the river might stay for long distance from their sources (Cukrov et al. 2008).

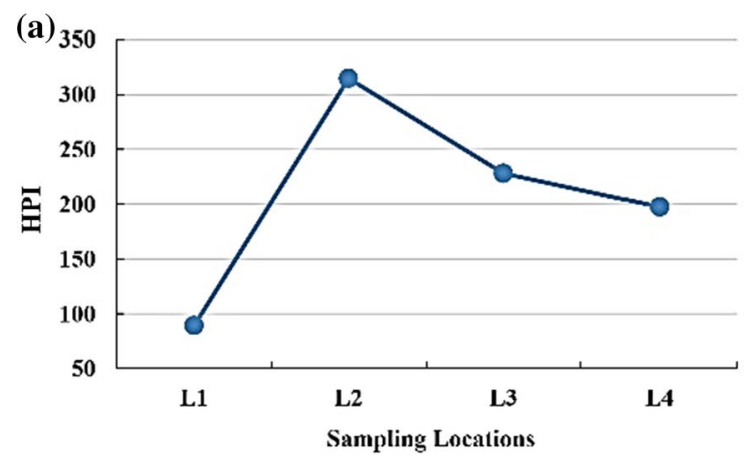

(c)

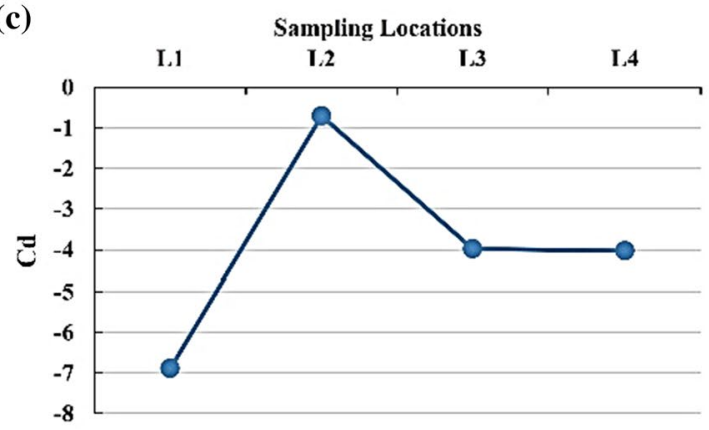

\section{Pollution evaluation indices of Diyala-Sirwan River}

Calculations of pollution evaluation indices HPI, HEI, $\mathrm{C}_{\mathrm{d}}$, $\mathrm{PI}$, and OIP in this study were based on river water quality standards taken from the literature (as illustrated in Table 1). For HPI, HEI, and $\mathrm{C}_{\mathrm{d}}$ indices, mean concentrations of heavy metals in water samples were implemented for the locations before and after the impact point of wastewater discharge. While for PI and OIP indices, physicochemical and heavy metals parameters dataset were used for the same locations mentioned before. In HPI calculations, ideal concentrations of heavy metals were adapted from literature (Cengiz et al. 2017; Herojeet et al. 2015; Issa and Alshatteri 2018).

Herojeet et al. (Herojeet et al. 2015) identified three classes for HPI pollution results: low $(<15)$; medium (15-30); and high ( $>30)$. While, the classification by HEI results for river pollution are; low $(<1.24)$, medium (1.24-2.48), and high ( $>2.48$ ) as stated by (Khoshnam et al. 2017). $C_{d}$ classification for river pollution are three classes: low $\left(C_{d}<1\right)$, medium $\left(C_{d}=1-3\right)$ and high $\left(C_{d}>3\right)$ (Clesceri et al. 1998).

Figure 3 displays values of HPI, HEI, $\mathrm{C}_{\mathrm{d}}$, and OIP, at location L2 of the impact point of wastewater discharge, there is a spike in all pollution indices: HPI increased from 89.31 to 314.69; HEI increased from 3.11 to 9.29; Cd increased from -6.89 to -0.71 ; OIP increased from 3.89 to 4.84 . According to HPI and HEI, Diyala-Sirwan river was already polluted and then with Kalar city wastewater discharge, the river has

(b)
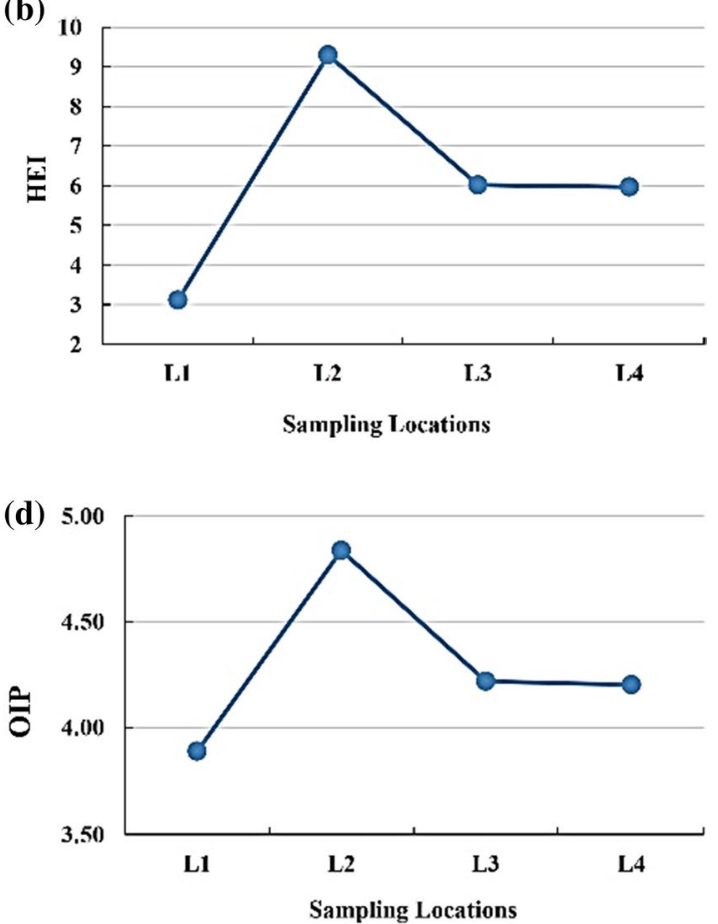

Fig. 3 Spatial distribution of pollution indices values within the study area 
been more polluted. $\mathrm{Cd}$ index indicates that the river water quality in terms of heavy metals pollution was not considerably impacted by the wastewater discharge as the river was slightly polluted before and after the impact point. Regarding OIP, Diyala-Sirwan river condition was changed from slightly polluted to be polluted at location L2. For locations L3 and L4, at 5 and $10 \mathrm{~km}$ after the impact point, generally the river could not regain the water quality condition to be similar to location L1 (before impact point). The reason for that might be the river was already carrying considerable concentrations of heavy metals before reaching the impact point and a high amount of pollutants was discharged by Kalar city wastewater into the river, which takes more time and longer distance to be naturally recovered.

Table 4 shows the PI results for the most important water quality parameters. Before the impact point, PI values range between 0.001 and 0.761 indicating no pollution effect in the river, except $\mathrm{PI}$ for $\mathrm{Al}$ was 1.038 meaning that the river was slightly affected by this parameter. After the impact point along with a distance of $10 \mathrm{~km}$, PI values range between 0.004 and 2.687, even though the values of all tested parameters were elevated, but the highest value was for $\mathrm{Hg}$ for which the river is considered a moderately polluted concerning the concentration of this heavy metal. Slight pollution effects were also noticed for $\mathrm{Al}$ and $\mathrm{Ca}$.

High PI value for $\mathrm{Al}$ before the impact point most likely comes from the water treatment plant of Kalar city, in which considerable amounts of aluminum sulfate are used and the resulted treatment sludge expelled without treatment into Diyala-Sirwan river. Otherwise, the elevated PI of $\mathrm{Hg}$ and $\mathrm{Ca}$ after impact point suggests a release of some industrial

Table 4 Pollution index PI of some water quality parameters and heavy metals for Diyala-Sirwan river with the study area

\begin{tabular}{lllll}
\hline Variable & $\begin{array}{l}\text { PI } \\
\text { (before } \\
\text { impact point) }\end{array}$ & Effect & $\begin{array}{l}\text { PI } \\
\text { (after impact } \\
\text { point) }\end{array}$ & Effect \\
\hline $\mathrm{T} . \mathrm{H}$ & 0.403 & No & 0.559 & No \\
$\mathrm{Ca}$ & 0.761 & No & 1.039 & Slightly \\
$\mathrm{K}$ & 0.148 & No & 0.439 & No \\
$\mathrm{Na}$ & 0.204 & No & 0.522 & No \\
$\mathrm{Mg}$ & 0.287 & No & 0.413 & No \\
$\mathrm{Al}$ & 1.038 & Slightly & 1.269 & Slightly \\
$\mathrm{As}$ & 0.060 & No & 0.122 & No \\
$\mathrm{Ba}$ & 0.057 & No & 0.074 & No \\
$\mathrm{Cu}$ & 0.012 & No & 0.016 & No \\
$\mathrm{Fe}$ & 0.191 & No & 0.346 & No \\
$\mathrm{Hg}$ & 0.500 & No & 2.687 & Moderately \\
$\mathrm{Mn}$ & 0.094 & No & 0.106 & No \\
$\mathrm{Ni}$ & 0.029 & No & 0.046 & No \\
$\mathrm{Se}$ & 0.219 & No & 0.288 & No \\
$\mathrm{Zn}$ & 0.001 & No & 0.004 & No \\
\hline
\end{tabular}

effluents into the city wastewater of these two parameters (Hammes et al. 2003; Wagner-Döbler et al. 2000).

\section{Health risk assessment of Diyala-Sirwan River due to wastewater discharge}

Three HI classes were proposed for non-carcinogenic effects by (Cui et al. 2015): $\mathrm{HI}$ is higher than 1, the risk is significant, $\mathrm{HI}$ is between 1 to 0.1 , the risk is moderately significant, and $\mathrm{HI}$ is less than 0.1 , the risk is neglected. From (Fig. 4), it can be seen that the total non-carcinogenic effects represented by HI on human health within the study area for people exposed to Diyala-Sirwan river by different pathways have variable risk potentials for the studied heavy metals. In general, all the heavy metals have HI values less than unity, suggesting that no significant effect is occurring on the people in the area. For non-carcinogenic risk, both As and $\mathrm{Hg}$ showed that they are moderately significant at sampling locations L2, L3, and L4. Additionally, Hg was not significant at L1, meaning that the risk was originated due to wastewater discharge in the river, while for As, HI results were increased after the impact point, showing that the wastewater discharge in the river contributed in increasing the risk of $\mathrm{Hg}$ existence in river water.

Sources of As in Diyala-Sirwan river and wastewater of Kalar city most probably are mixed from natural origins such as soil and rocks weathering, and from anthropogenic activities, which is mainly for the study area are fossil combustion and application of arsenic-containing fertilizers and pesticides for agricultural purposes (Ungureanu et al. 2015).

Figure 4 shows that carcinogenic risk of As in water samples at sampling location was $1.134 * 10^{-4}$, and after impact point was ranging from $1.323 * 10^{-4}$ to $1.89^{*} 10^{-4}$, presenting significant carcinogenic risk. These results show that direct exposure to Diyala-Sirwan river at the study area is unsafe, as these results are fallen within a suggested range, between $10^{-4}$ and $10^{-6}$, of potential carcinogenic risk (USEPA 2010).

The carcinogenic risk of As, which is determined as an incremental probability in lifetime risk that might cause cancer for any individual as a result of drinking water consumption or through dermal exposure (Iqbal and Shah 2013), might cause many serious kinds of cancer in the human body like cancer of liver, lung, kidney, skin, and bladder (Banerjee et al. 2011). Regarding health risk assessment, it is worth mentioning that the approach applied in this study involves parameters of SF, $\mathrm{K}_{\mathrm{p}}$, and RfD might not be exactly compatible with Iraqi conditions. Therefore, the current study is only preliminary evaluation of Diyala-Sirwan river condition after wastewater discharge has occurred, so more studies are required to figure out more precisely the risk arising from mixing Kalar city wastewater with the river water and subsequent effects on people and living creatures in the area. 

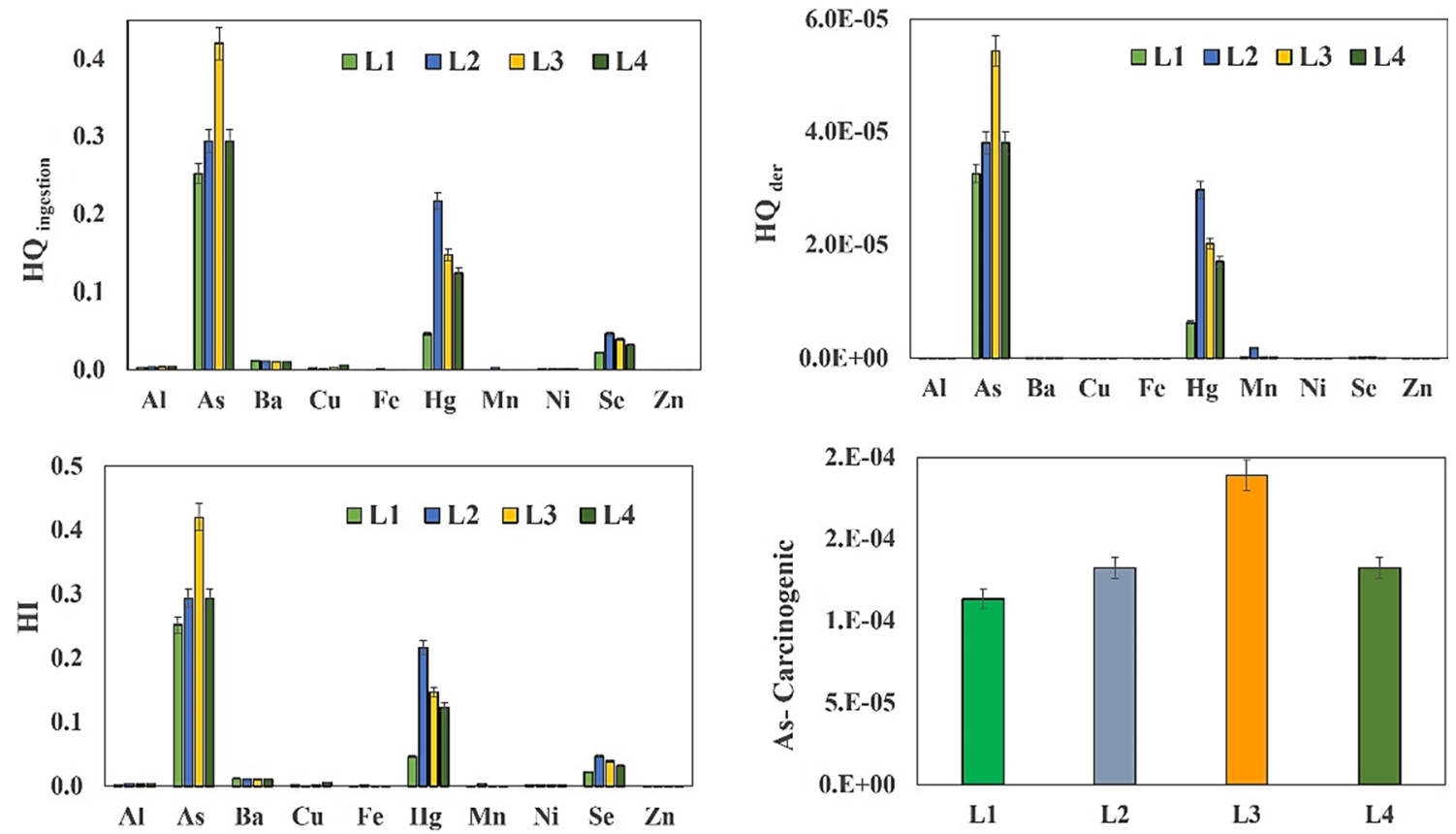

Fig. $4 \mathrm{HQ}_{\text {ingestion }}, \mathrm{HQ}_{\text {der }}$, $\mathrm{HI}$, and As cancer risk for each heavy metal of Diyala-Sirwan river at all sampling locations

\section{Conclusions}

In this work, different evaluation methods have been performed for physicochemical and heavy metals water quality parameters of Diyala-Sirwan river impacted by wastewater discharge from Kalar city, east of Iraq. Results of pollution indices, HIP, HEI, Cd, Pi, and OIP, indicated that the river was considerably impacted by the wastewater discharge, showing that heavy metals concentrations were remarkably elevated within the study area. Multivariate statistics, CA and CM, revealed that the impact of wastewater discharge on river water quality remained significant in water samples collected from all sampling locations after the wastewater impact point. The health risk assessment showed wastewater discharge into the river was most likely responsible for considerable non-carcinogenic of the investigated heavy metals, and carcinogenic risk of both As and $\mathrm{Hg}$ on individuals in the study area. The results obtained in this study are important to build a reliable system for environmental monitoring and measuring pollution of Diyala-Sirwan river.

Funding No funding was received for conducting this study.

\section{Declarations}

Conflict of interest The authors declare that there is no conflict of interest regarding the publication of this paper.
Human and animal rights This article does not contain any studies involving human participants or animals performed by any of the authors.

Open Access This article is licensed under a Creative Commons Attribution 4.0 International License, which permits use, sharing, adaptation, distribution and reproduction in any medium or format, as long as you give appropriate credit to the original author(s) and the source, provide a link to the Creative Commons licence, and indicate if changes were made. The images or other third party material in this article are included in the article's Creative Commons licence, unless indicated otherwise in a credit line to the material. If material is not included in the article's Creative Commons licence and your intended use is not permitted by statutory regulation or exceeds the permitted use, you will need to obtain permission directly from the copyright holder. To view a copy of this licence, visit http://creativecommons.org/licenses/by/4.0/.

\section{References}

Abdel-Satar AM, Ali MH, Goher ME (2017) Indices of water quality and metal pollution of Nile River. Egypt The Egyptian J Aquat Res 43:21-29. https://doi.org/10.1016/j.ejar.2016.12.006

Abdullah EJ (2013) Evaluation of surface water quality indices for heavy metals of Diyala River-Iraq. J Natural Sci Res. 3

Ali MM, Ali ML, Islam MS, Rahman MZ (2016) Preliminary assessment of heavy metals in water and sediment of Karnaphuli River. Bangladesh Environ Nanotechnol, Monitor Manag 5:27-35. https://doi.org/10.1016/j.enmm.2016.01.002

Aris AZ, Kam RCY, Lim AP, Praveena SM (2013) Concentration of ions in selected bottled water samples sold in Malaysia Applied Water. Science 3:67-75 
Aziz SQ (2016) Fakhrey ESa The effect of kawergosk oil refinery wastewater on surrounding water resources Zanco. J Pure Appl Sci 28:656-667

Aziz SQ, Abdullah WA, Slewa EO (2018) Effect of Alton Kopri Wastewater on Lesser-SSr Tikrit Journal of. Eng Sci 25:18-26

Banerjee M, Bhattacharjee P, Giri AK (2011) Arsenic-induced cancers: a review with special reference to gene, environment and their interaction. Genes and environment 33:128-140

Bastami KD, Bagheri H, Haghparast S, Soltani F, Hamzehpoor A, Bastami MD (2012) Geochemical and geo-statistical assessment of selected heavy metals in the surface sediments of the Gorgan Bay. Iran Mar Pollut Bull 64:2877-2884. https://doi. org/10.1016/j.marpolbul.2012.08.015

Begum A, Ramaiah M, Harikrishna Khan I, Veena K (2009) heavy metal pollution and chemical profile of cauvery river water. E-J Chem 6:154610. https://doi.org/10.1155/2009/154610

Bhuiyan MA, Islam M, Dampare SB, Parvez L, Suzuki S (2010) Evaluation of hazardous metal pollution in irrigation and drinking water systems in the vicinity of a coal mine area of northwestern Bangladesh. J Hazard Mater 179:1065-1077

Bhuiyan MAH, Dampare SB, Islam MA, Suzuki S (2014) Source apportionment and pollution evaluation of heavy metals in water and sediments of Buriganga River. Bangladesh, using multivar analy pollut evaluat indice Environ Monit Assess 187:4075. https://doi.org/10.1007/s10661-014-4075-0

Boateng TK, Opoku F, Acquaah SO, Akoto O (2015) Pollution evaluation, sources and risk assessment of heavy metals in hand-dug wells from Ejisu-Juaben Municipality. Ghana Environmental Systems Research 4:18

Cengiz MF, Kilic S, Yalcin F, Kilic M, Yalcin MG (2017) Evaluation of heavy metal risk potential in Bogacayi River water (Antalya, Turkey) Environ Monit Assess 189:248

Clesceri LS, Eaton AD, Greenberg AE, Association APH, Association AWW, Federation WE (1998) Standard Methods for the Examination of Water and Wastewater. American Public Health Association

Cui X-Y, Li S-W, Zhang S-J, Fan Y-Y, Ma LQ (2015) Toxic metals in children's toys and jewelry: coupling bioaccessibility with risk assessment. Environ Pollut 200:77-84. https://doi.org/10.1016/j. envpol.2015.01.035

Cukrov N, Cmuk P, Mlakar M, Omanović D (2008) Spatial distribution of trace metals in the Krka River, Croatia: an example of the self-purification. Chemosphere 72:1559-1566. https://doi.org/10. 1016/j.chemosphere.2008.04.038

De Miguel E, Iribarren I, Chacón E, Ordoñez A, Charlesworth S (2007) Risk-based evaluation of the exposure of children to trace elements in playgrounds in Madrid (Spain). Chemosphere 66:505513. https://doi.org/10.1016/j.chemosphere.2006.05.065

Diagomanolin V, Farhang M, Ghazi-Khansari M, Jafarzadeh N (2004) Heavy metals $(\mathrm{Ni}, \mathrm{Cr}, \mathrm{Cu})$ in the Karoon waterway river. Iran Toxicol Lett 151:63-67. https://doi.org/10.1016/j.toxlet.2004.02.018

Edet A, Offiong O (2002) Evaluation of water quality pollution indices for heavy metal contamination monitoring. A study case from Akpabuyo-Odukpani area, lower cross river Basin (southeastern Nigeria). GeoJournal 57:295-304

Effendi H (2016) River water quality preliminary rapid assessment using pollution index. Procedia Environ Sci 33:562-567. https:// doi.org/10.1016/j.proenv.2016.03.108

US EPA (2004) Risk Assessment Guidance for Superfund Volume I: Human Health Evaluation Manual

Giri S, Singh AK (2014) Assessment of surface water quality using heavy metal pollution index in Subarnarekha River. India Water Quality, Exposure Health 5:173-182. https://doi.org/10.1007/ s12403-013-0106-2

Giri S, Singh AK (2015) Human health risk assessment via drinking water pathway due to metal contamination in the groundwater of
Subarnarekha River Basin. India Environ Monit Assess 187:63. https://doi.org/10.1007/s10661-015-4265-4

Goher ME, Hassan AM, Abdel-Moniem IA, Fahmy AH, El-sayed SM (2014) Evaluation of surface water quality and heavy metal indices of Ismailia Canal. Nile River, Egypt The Egyptian Journal of Aquatic Research 40:225-233. https://doi.org/10.1016/j.ejar. 2014.09.001

Gonzalez MJ, Fernandez M, Hernandez LM (1990) Influence of acid mine water in the distribution of heavy metal in soils of Donana national park. Appl multivar analy Environ Technol 11:10271038. https://doi.org/10.1080/09593339009384957

Hammes F, Seka A, Van Hege K, Van de Wiele T, Vanderdeelen J, Siciliano SD, Verstraete W (2003) Calcium removal from industrial wastewater by bio-catalytic $\mathrm{CaCO} 3$ precipitation. $\mathrm{J}$ Chem Technol Biotechnol 78:670-677. https://doi.org/10.1002/ jctb. 840

Hassan FM, Saleh MM, Salman JM (2010) A Study of Physicochemical Parameters And Nine Heavy Metals In The Euphrates River. Iraq E-J Chem. https://doi.org/10.1155/2010/906837

Hassan FM, Al-Jibouri KDW, Hakman AA (2017) Water quality assessment of Diyala river in Diyala province. Iraq Mesopotamia Environ J 4:52-61

Herojeet R, Rishi MS, Kishore N (2015) Integrated approach of heavy metal pollution indices and complexity quantification using chemometric models in the Sirsa Basin. Nalagarh valley, Himachal Pradesh, India Chinese J Geochem 34:620-633. https://doi.org/10.1007/s11631-015-0075-1

Ibrahim MA (2012) Assessment of water quality status for the Euphrates River in Iraq. Eng Technol J 30:2536-2549

Iqbal J, Shah MH (2013) Health Risk Assessment of Metals in Surface Water from Freshwater Source Lakes. Pakistan Human and Ecological Risk Assessment: An International Journal 19:1530 1543. https://doi.org/10.1080/10807039.2012.716681

Ismaiel IA, Bird G, McDonald MA, Perkins WT, Jones TG (2018) Establishment of background water quality conditions in the Great Zab River catchment: influence of geogenic and anthropogenic controls on developing a baseline for water quality assessment and resource management. Environ Earth Sci 77:50. https://doi.org/10.1007/s12665-017-7190-8

Issa HM (2014) An Initial Environmental Assessment for the Potential Risk of the Developing Industry Impact on the Surface Water Resources in the Kurdistan Region-Iraq. J Garmian Univ:35-48

Issa HM (2017) Evaluation of water quality and performance for a water treatment plant: Khanaqin City as a case study. J Garmian Univ 3:802-821. https://doi.org/10.24271/garmian.64

Issa HM, Alshatteri A (2018) Assessment of heavy metals contamination in drinking water of Garmian Region. Iraq UHD J Sci Technol 2:40-53. https://doi.org/10.21928/uhdjst.v2n2y2018.pp40-53

Jadoon S, Hilala Z, Alia M, Muhammada S (2019) Potentially toxic elements in drinking water and associated health risk assessment in Abbottabad city, northern Pakistan. Desalinat Water Treat 159:392-402. https://doi.org/10.5004/dwt.2019.23909

Jiang X, Teng A, Xu W, Liu X (2014) Distribution and pollution assessment of heavy metals in surface sediments in the Yellow Sea. Mar Pollut Bull 83:366-375. https://doi.org/10.1016/j.marpolbul. 2014.03.020

Kamil WS, Adel Abdulrazzaq K (2010) Construction water suitability maps of Tigris River For irrigation and drinking use. J Eng-Iraq 16:5822-5841

Kaushik A, Kansal A, Santosh M, Kumari S, Kaushik CP (2009) Heavy metal contamination of river Yamuna, Haryana, India: assessment by metal enrichment factor of the sediments. J Hazard Mater 164:265-270. https://doi.org/10.1016/j.jhazmat.2008.08.031

Khoshnam Z, Sarikhani R, Ahmadnejad Z (2017) Evaluation of water quality using heavy metal index and multivariate statistical 
analysis in Lorestan Province. Iran J Adv Environ Health Res 5:29-37

Kurdistan Region Statistics Office (2020) A published Report. Erbil, Kurdistan Region, Iraq

Li S, Zhang Q (2010) Risk assessment and seasonal variations of dissolved trace elements and heavy metals in the Upper Han River. China J Hazard Mater 181:1051-1058. https://doi.org/10.1016/j. jhazmat.2010.05.120

Mahmood SHR (2010) Hydro chemical and some biological properties and pollution level in water of euphrates River for Ramadi city. W-Iraq Anbar J Agri Sci 8:13-22

Marcovecchio JE, Botté SE, Freije RH (2007) Heavy metals, major metals,(eds) Leo Nollet trace elements Handbook of water analysis. CRC Press

Mohan SV, Nithila P, Reddy SJ (1996) Estimation of heavy metals in drinking water and development of heavy metal pollution index. J Environ Sci Health Part A 31:283-289

$\mathrm{Mu} \mathrm{X}$ et al (2015) Using integrated multivariate statistics to assess the hydrochemistry of surface water quality. Lake Taihu basin, China J Limnol 74:234-247

Muhammad S, Ahmad K (2020) Heavy metal contamination in water and fish of the Hunza River and its tributaries in Gilgit-Baltistan: Evaluation of potential risks and provenance. Environ Technol Innovat 20:101159. https://doi.org/10.1016/j.eti.2020.101159

Nasrabadi T (2015) An indexapproach to metallic pollution in River Waters. Int J Environ Res 9:385-394

Özgür ME, Akbulut A, Demirsoy A (2012) Some quality parameters of susrace water of Karasu River in upper part of Euphrates Basin. Turkey Carpathian J Earth Environ Sci 7:183-192

Prasad B, Bose J (2001) Evaluation of the heavy metal pollution index for surface and spring water near a limestone mining area of the lower Himalayas. Environ Geol 41:183-188. https://doi.org/10. $1007 / \mathrm{s} 002540100380$

Protano C, Zinnà L, Giampaoli S, Spica VR, Chiavarini S, Vitali M (2014) Heavy metal pollution and potential ecological risks in rivers: a case study from Southern Italy. Bull Environ Contam Toxicol 92:75-80. https://doi.org/10.1007/s00128-013-1150-0

Razzak I, Sulaymon AH (2009) Effects of discharging sewage of Baghdad to Tigris River on the Water Quality. Eng Tech J 27:27

Reza R, Singh G (2010) Heavy metal contamination and its indexing approach for river water Int J. Environ Sci Technol 7:785-792

Rice EW, Baird RB, Eaton AD (2017) APHA 2017 Standard Methods for the Examination of Water and Wastewater. 23rd edn. American Public Health Association, American Water Works Association, Water Environment Federation (AWWA, WEF and APHA), Washington

Salah EAM, Zaidan TA, Al-Rawi AS (2012) Assessment of heavy metals pollution in the sediments of Euphrates River. Iraq J Water Res Protect 04(12):15. https://doi.org/10.4236/jwarp.2012.412117

Sargaonkar A, Deshpande V (2003) Development of an Overall Index of Pollution for Surface Water Based on a General Classification Scheme in Indian Context. Environ Monit Assess 89:43-67. https://doi.org/10.1023/A:1025886025137

Sharda A, Sharma M (2013) Water quality assessment of Swan River in Himachal Pradesh. India Int J Environ Sci 4:402-414

Simeonov V et al (2003) Assessment of the surface water quality in Northern Greece. Water Res 37:4119-4124. https://doi.org/10. 1016/S0043-1354(03)00398-1

Singaraja C, Chidambaram S, Srinivasamoorthy K, Anandhan P, Selvam S (2015) A study on assessment of credible sources of heavy metal pollution vulnerability in groundwater of Thoothukudi districts. Tamilnadu, India Water Quality, Exposure and Health 7:459-467

Sörme L, Lagerkvist R (2002) Sources of heavy metals in urban wastewater in Stockholm. Sci Total Environ 298:131-145. https://doi. org/10.1016/S0048-9697(02)00197-3

Suresh G, Sutharsan P, Ramasamy V, Venkatachalapathy R (2012) Assessment of spatial distribution and potential ecological risk of the heavy metals in relation to granulometric contents of Veeranam lake sediments. India Ecotoxicol Environ Saf 84:117-124. https://doi.org/10.1016/j.ecoenv.2012.06.027

Tripathee L, Kang S, Sharma CM, Rupakheti D, Paudyal R, Huang J, Sillanpää M (2016) Preliminary health risk assessment of potentially toxic metals in surface water of the Himalayan Rivers. Nepal Bull Environ Contam Toxicol 97:855-862. https://doi.org/10. 1007/s00128-016-1945-x

Ullah R, Muhammad S, Jadoon IAK (2019) Potentially harmful elements contamination in water and sediment: evaluation for risk assessment and provenance in the northern Sulaiman fold belt. Baluchistan, Pakistan Microchem J 147:1155-1162. https://doi. org/10.1016/j.microc.2019.04.053

Ungureanu G, Santos S, Boaventura R, Botelho C (2015) Arsenic and antimony in water and wastewater: overview of removal techniques with special reference to latest advances in adsorption. J Environ Manage 151:326-342. https://doi.org/10.1016/j.jenvm an.2014.12.051

Garmian Region Agriculture Department (2017) Unpublished reports

USEPA (2010) Risk-Based Concentration Table. United States Environmental Protection Agency

Varol M, Şen B (2012) Assessment of nutrient and heavy metal contamination in surface water and sediments of the upper Tigris River. Turkey CATENA 92:1-10. https://doi.org/10.1016/j.catena. 2011.11.011

Wagner-Döbler I, von Canstein H, Li Y, Timmis KN, Deckwer W-D (2000) Removal of mercury from chemical wastewater by microoganisms in technical scale. Environ Sci Technol 34:4628-4634. https://doi.org/10.1021/es0000652

Wang J, Liu G, Liu H, Lam PKS (2017) Multivariate statistical evaluation of dissolved trace elements and a water quality assessment in the middle reaches of Huaihe River. Anhui, China Sci Total Environ 583:421-431. https://doi.org/10.1016/j.scitotenv.2017.01.088

Wissam A-M, Isam A (2017) Evaluation of environmental performance of wastewater treatment plants in countries with crisis: case study from Iraq Muthanna. J Eng Technol (MJET) 5:67-76

World Health Organization (2017) Water quality and health-review of turbidity: information for regulators and water suppliers. World Health Organization,

Wu B, Zhao DY, Jia HY, Zhang Y, Zhang XX, Cheng SP (2009) Preliminary risk assessment of trace metal pollution in surface water from Yangtze River in nanjing section. China Bull Environ Contam Toxicol 82:405-409. https://doi.org/10.1007/ s00128-008-9497-3

Wu Z, Wang X, Chen Y, Cai Y, Deng J (2018) Assessing river water quality using water quality index in Lake Taihu Basin. China Sci Total Environ 612:914-922. https://doi.org/10.1016/j.scitotenv. 2017.08.293

Publisher's Note Springer Nature remains neutral with regard to jurisdictional claims in published maps and institutional affiliations. 